УДК 351

DOI: https://doi.org/10.26642/jen-2020-4(94)-150-159

Ф.Р. Криничко, здобувач

Державний університет «Житомирська політехніка»

\title{
Оцінка стану дитячої смертності як складова державної політики в сфері громадського здоров'я
}

\author{
(Представлено: д.держ.упр., дои.. Антонов А.В.)
}

\begin{abstract}
Народжуваність, стан здоров'я населення та дитяча смертність є важливими показниками якості життя кожної держави. Аналіз наукової літератури в частині питань державного управління системою охорони здоров'я дозволяє зауважити, щз ичю сферу досліджувало багато науковців, однак оцінка стану дитячої смертності як складової державної політики вивчена досить фрагментно, щзо актуалізує ие дослідження. Таким чином мета статті полягає в досліджені оцінки стану дитячої смертності як складової державної політики в сфері громадського здоров'я. Очінку стану дитячої смертності було здійснено за такими напрямами: проаналізовано показники дитячої смертності у краӥнах Близького Сходу та Північної Африки, здійснено оцінку коефіцієнта дитячої смертності у країнах Східної, Західної та Центральної Африки; Південної, Південно-Східної, Центральної, Східної та Південно-Західної Азї̈; Південноі та Північної Америки; Австралії та Океанії; Центральної Америки та Кариби; Західної, Північної; Південної та Східної Свропи. Провівши дослідження оцінки коефіцієнта дитячої смертності, слід зауважити, щзо значна кількість випадків дитячої смертності зафіксована у Мавританії, Судані, Індії, Філіппінах, Камбоджі, Таджикистані, Монголії, Афганістані, Парагваї, Венесуелі, Науру, Домініканській Республіці та Азербайджані.
\end{abstract}

Ключові слова: очінка; коефічієнт дитячої смертності; аналіз; державна політика; громадське здоров'я; охорона здоров'я.

Постановка проблеми. На сучасному етапі розвитку кожної держави важливими показниками якості життя $\epsilon$ народжуваність, стан здоров'я населення та дитяча смертність. Основними чинниками рівня соціально-економічного розвитку країни є кількісна характеристика дитячих смертей, яка визначає наскільки ефективно працює система охорони здоров'я та як якісно й вчасно надається медична допомога дітям.

Аналіз останніх досліджень та публікацій. Здійснивши аналіз наукової літератури в частині питань державного управління системою охорони здоров'я, варто зазначити, що їх досліджували такі вітчизняні та зарубіжні вчені, зокрема: Т.П. Авраменко, О.В. Балуєва, М.М. Білинська, В.Д. Долот, Л.І. Жаліло, В.О. Жаховський, Д.В. Карамишев, О.Д. Крикун, О.І. Мартинюк, В.П. Мегедь, Л.А. Мельник, С.Я. Пак, С.М. Петрик, Я.Ф. Радиш, Я.Ф. Радиш, І.В. Рожкова, Л.В. Сергієнко, І.І. Хожило та інші. Однак питання оцінки стану дитячої смертності як складової державної політики залишаються поза увагою науковців.

Мета статті - здійснити оцінку стану дитячої смертності як складової державної політики в сфері громадського здоров'я.

Викладення основного матеріалу. «Показники дитячої смертності в країнах світу регулярно розраховуються в рамках спеціальної програми міжвідомчого агентства Організації Об'єднаних Націй по оцінці дитячої смертності (МГДС ООН) на основі статистичних даних, одержуваних від національних інститутів і міжнародних організацій. У програмі беруть участь дослідницькі центри Дитячого фонду Організації Об'єднаних Націй (ЮНІСЕФ), Департаменту Організації Об’єднаних Націй з економічних та соціальних питань (ДЕСВ ООН), Програми розвитку Організації Об'єднаних Націй (ПРООН), Всесвітньої організації охорони здоров’я (ВОО3) і Світового банку. Для підвищення прозорості процесу оцінки МГДС ООН розробила вебпортал childmortality.org, присвячений показниками дитячої смертності, на якому розміщуються всі наявні дані і наводяться оцінки по кожній країні, а також відомості про дані, які в даний час офіційно використовує МГДС ООН для їх розрахунку»[6].

Коефіцієнт дитячої смертності застосовується як засіб аналізу для побудови порівняльних рейтингів, що відображають якість життя населення в різних країнах, а також використовується для розрахунку Індексу людського розвитку (Human Development Index) в межах спеціальної серії доповідей ООН про розвиток людини. При визначенні місця в глобальному рейтингу всі країни ранжуються на основі цього показника, де перше місце в рейтинговій таблиці відповідає нижчому значенню цього показника, а останнє - найвищому [6].

На рисунку 1 вказано показники дитячої смертності у країнах Близького Сходу та Північної Африки. 


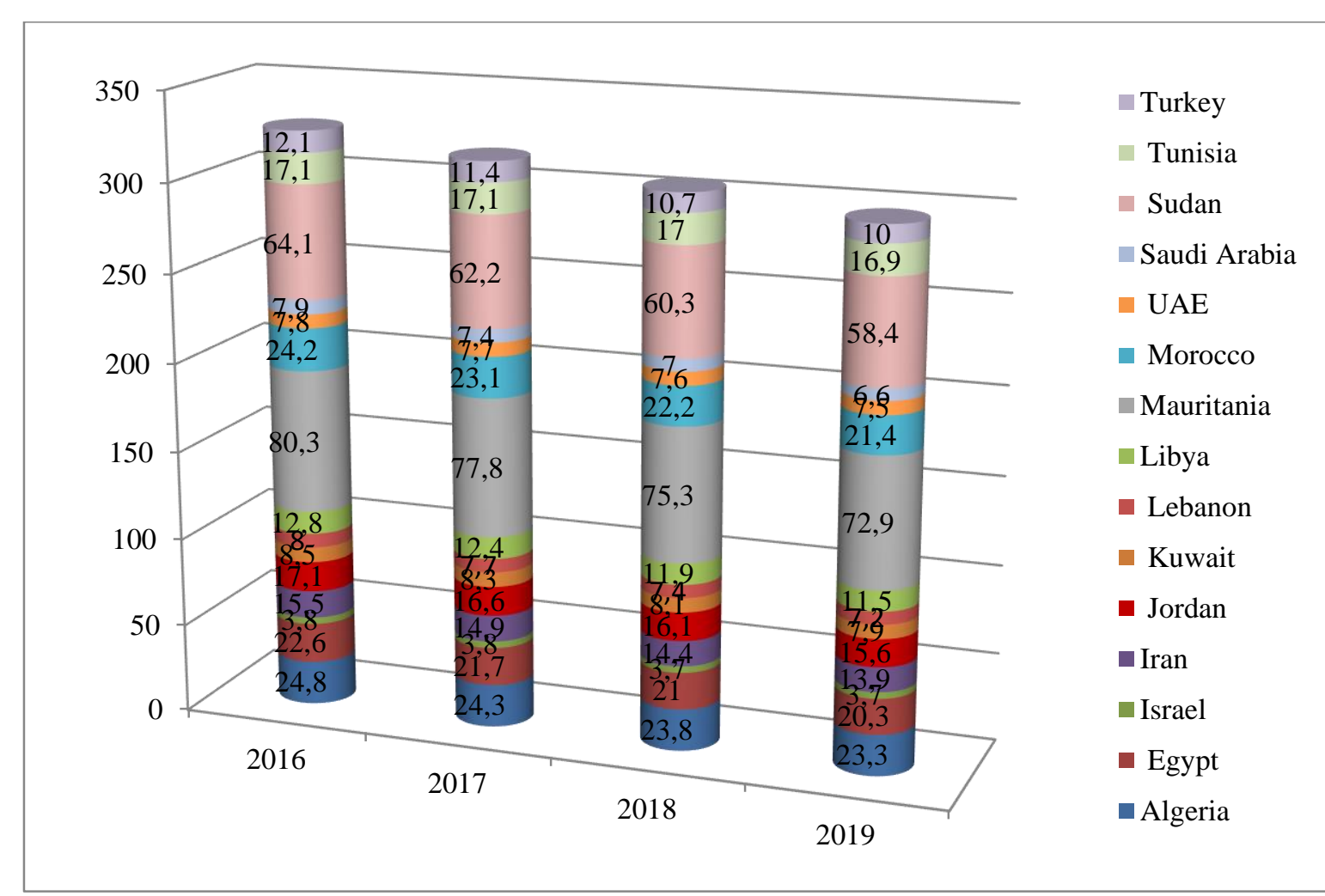

Джерело: сформовано на основі [2-5]

Рис. 1. Оцінка коефіцієнта смертності серед дітей віком до 5 років у краӥнах Близького Сходу та Північної Африки, 2016-2019 рр.

Серед країн Близького Сходу та Північної Африки найвищі показники протягом 2016-2019 pp. зосереджені у Мавританії та Судані. Оскільки показники смертності у Мавританії коливаються в межах 72,9-80 смертей на 1000 живонароджених, хоча у цій країні спостерігається тенденція до зменшення показника протягом вказаного періоду, але все ж таки дитяча смертність залишається на досить високому рівні. У Судані показник дитячої смертності знаходиться у межах 58,4-64,1 смертей на 1000 живонароджених, що є негативним фактором, який пов'язаний з недосконалою медициною, однак протягом 2016-2019 рр. простежується тенденція до зменшення показника дитячої смертності. Головними причинами дитячої смертності в зазначених регіонах є інфекційні захворювання, хронічне недоїдання та голод. Найменші показники смертності серед країн Близького Сходу та Північної Африки зафіксовані у Ізраїлі, адже показник смертності коливається з 2016 по 2019 рр. у межах 3,7-3,8 смертей на 1000 живонароджених.

У країнах Східної, Західної та Центральної Африки (рис. 2) показник дитячої смертності є найвищим серед інших регіонів світу. Нігерія протягом 2016-2019 рр. займає перші місця у світовому рейтингу дитячої смертності, адже показник знаходиться у межах 117,2-125 смертей на 1000 живонароджених. Високі показники смертності спостерігаються серед країн Африки у Малі, Гвінеї, Центральноафриканській республіці, Чаді та Сомалі. Показники смертності у цих регіонах протягом 2016-2019 рр. становлять понад 100 смертей на 1000 живонароджених. Зокрема, у Малі кількість померлих дітей віком до 5 років у 2016 р. становила близько 104,8 смертей на 1000 живонароджених, а вже на кінець 2019 р. показник дещо знизився та становив 94 на 1000 живонароджених. У Гвінеї показник смертності коливається у межах 98,8-105,2 смертей на 1000 живонароджених, у Центральноафриканській республіці - 110,1-121,6 дитячих смертей на 1000 новонароджених. У Республіці Чад та Сомалі у 2016 р. показники дитячої смертності були найвищими серед інших країн Африки, оскільки становили 125,6 та 128,4 смертей на 1000 живонароджених. На кінець 2019 р. відбулося скорочення смертності серед дітей віком до 5 років та становило близько 113,8 смертей у Чаді та 117 смертей у Сомалі. Найменші показники дитячої смертності зосереджені у Руанді, Сенегалі, Гані, Уганді та Кенії. Зокрема, у Руанді дитяча смертність становила протягом досліджуваного періоду 39,2034,3 смертей на 1000 живонароджених. Для решти країн показник смертності складав понад 50 смертей на 1000 живонароджених протягом 2016-2019 рр. 


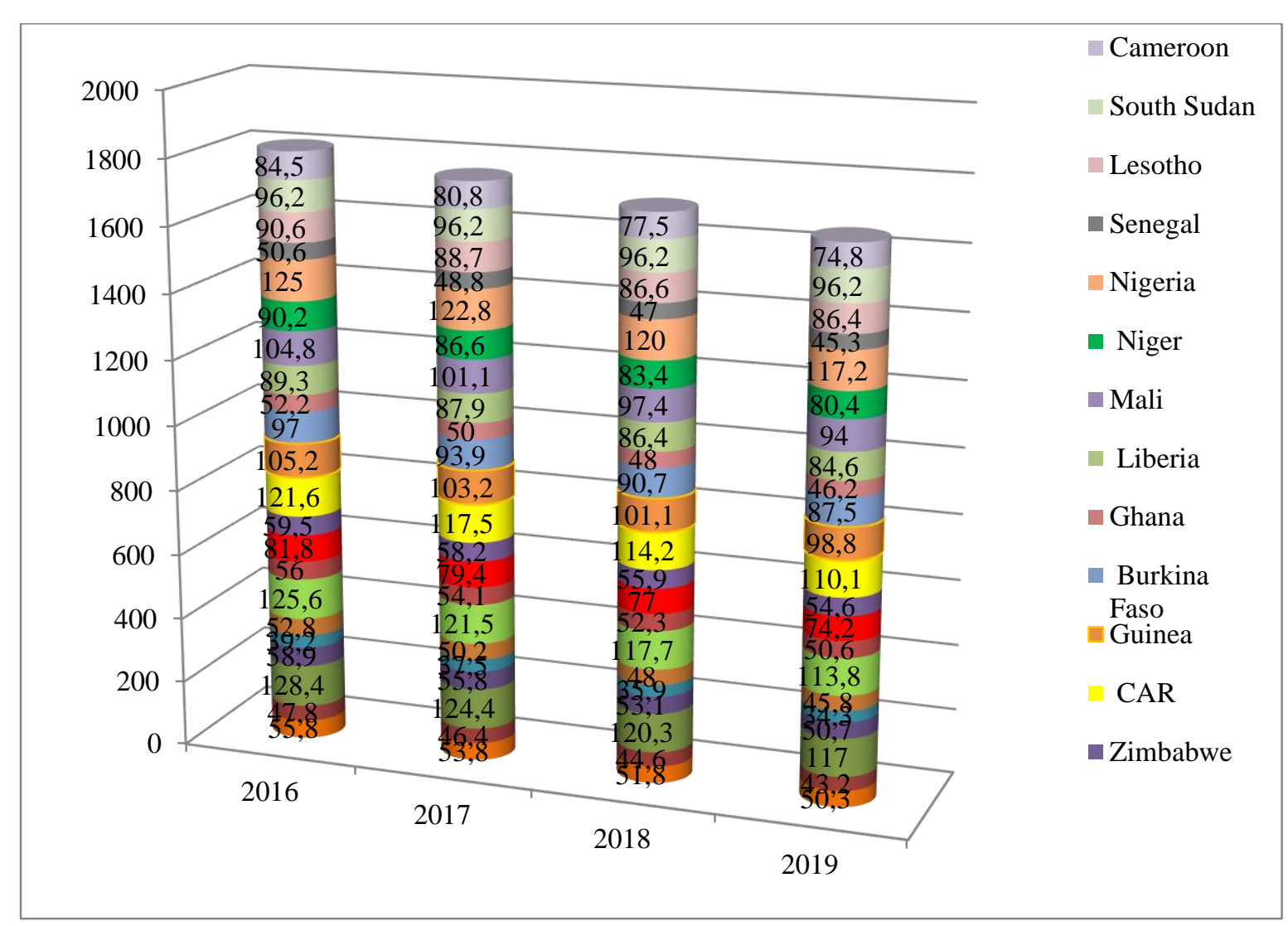

Джерело: сформовано на основі [2-5]

Рис. 2. Оичінка коефіиієнта смертності серед дітей віком до 5 років у країнах Східної, Західної та Центральної Африки, 2016-2019 рр.

На рисунку 3 наведено показник дитячої смертності у країнах Південної Азії. Серед цих країн найвищий показник смертності серед дітей віком до 5 років зафіксований у Індії, це пов'язано перш за все $з$ недоїданням, неонатальними захворюваннями, діареєю та пневмонією. Наступними країнами за чисельність смертей $є$ Непал та Бангладеш, показники дитячої смертності яких коливаються в межах 34,6-30,8 та 35,7-30,8 смертей на 1000 живонароджених. Найменший показник дитячої смертності зосереджений у Шрі-Ланці протягом досліджуваного періоду та коливається в межах 7,1-8,2 смертей на 1000 новонароджених та при цьому спостерігається тенденція до зменшення показника смертності дітей віком до 5 років.

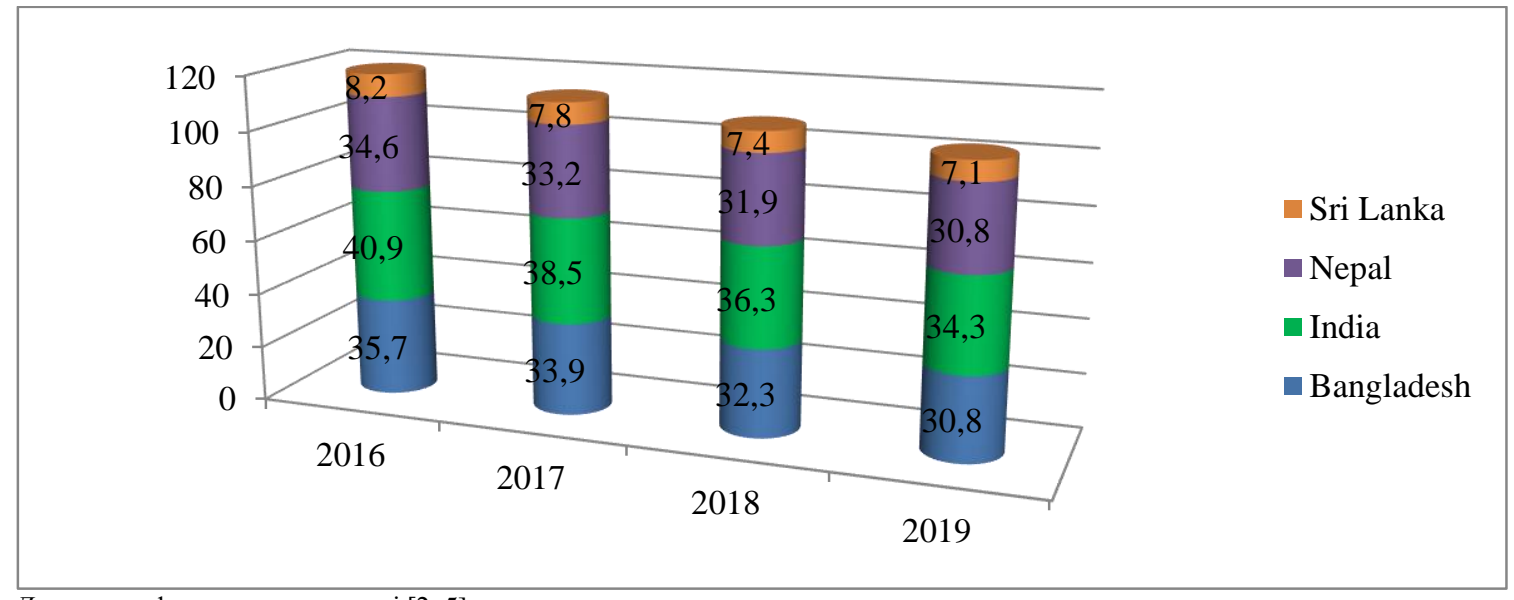

Джерело: сформовано на основі [2-5]

Рис. 3. Оцінка коефіцієнта смертності серед дітей віком до 5 років у краӥнах Південної Азії, 2016-2019 рр. 
Що стосується коефіцієнта дитячої смертності серед країн Південно-Східної Азії (рис. 4), то найвищий показник зазначено на Філіппінах та Камбоджі. Зокрема, на Філіппінах показник дитячої смертності протягом 2016-2019 pp. вказаний в межах близько 27,3-29,3 смертей на 1000 новонароджених, у Камбоджі показник - у межах 26,6-30,1 смертей на 1000 новонароджених. Основною причиною смертей у цих регіонах є захворювання на кір, яке дуже швидко розповсюджується. Дещо менші показники смертності зосереджені у двох інших регіонах Південно-Східної Азії, а саме у Таїланді та Малайзії. У Таїланді показник смертності скоротився протягом 2016-2019 pp. 3 10,3 до 9,0 смертей на 1000 новонароджених. У Малайзії зафіксовано найменший показник смертності дітей віком до 5 років, який коливався в межах 8,2-8,6 смертей на 1000 новонароджених.

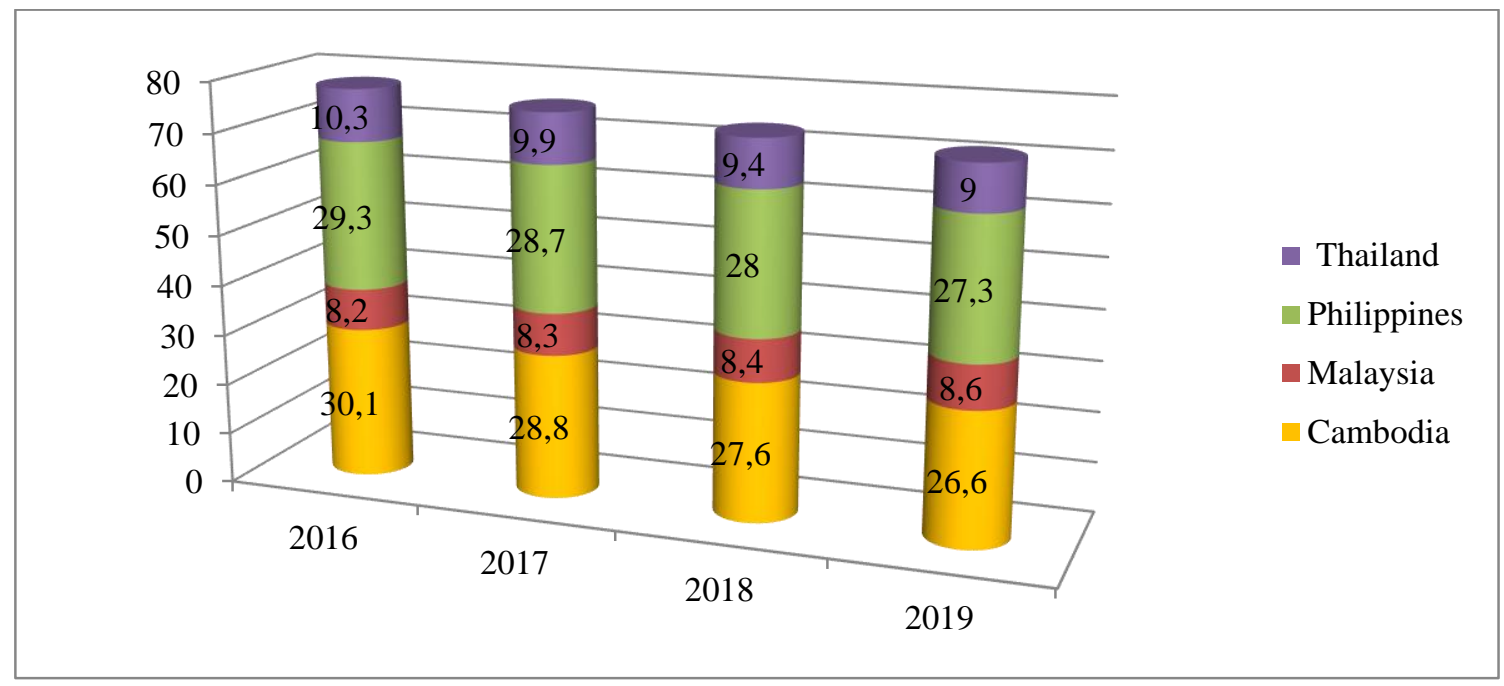

Джерело: сформовано на основі [2-5]

Рис. 4. Оччінка коефіцієнта смертності серед дітей віком до 5 років у краӥнах Південно-Східної Азї, 2016-2019 рр.

На рисунку 5 зазначено показники дитячої смертності у країнах Центральної Азії. Найвищий показник дитячої смертності зафіксований у Таджикистані, оскільки у 2016-2019 рр. коливався в межах 33,8-36,8 смертей на 1000 живонароджених. Велика смертність у цьому регіоні пов'язана 3 неонатальною смертністю, недотриманням санітарних норм у пологових будинках, діареєю у дітей, хронічним недоїданням [1]. Наступними регіонами за кількістю дитячих смертності є Узбекистан та Киргизстані. В Узбекистані протягом досліджуваного періоду зафіксована тенденція до зменшення показника дитячої смертності з 21,1 до 17,4 смертей на 1000 живонароджених, у Киргизстані спостерігається також зменшення показника 3 21,2 до 18,3 смертей на 1000 живонароджених. Найменший показник дитячої смертності зосереджений у Казахстані, оскільки значення показника коливалося в межах 10,5-11,00 смертей на 1000 живонароджених.

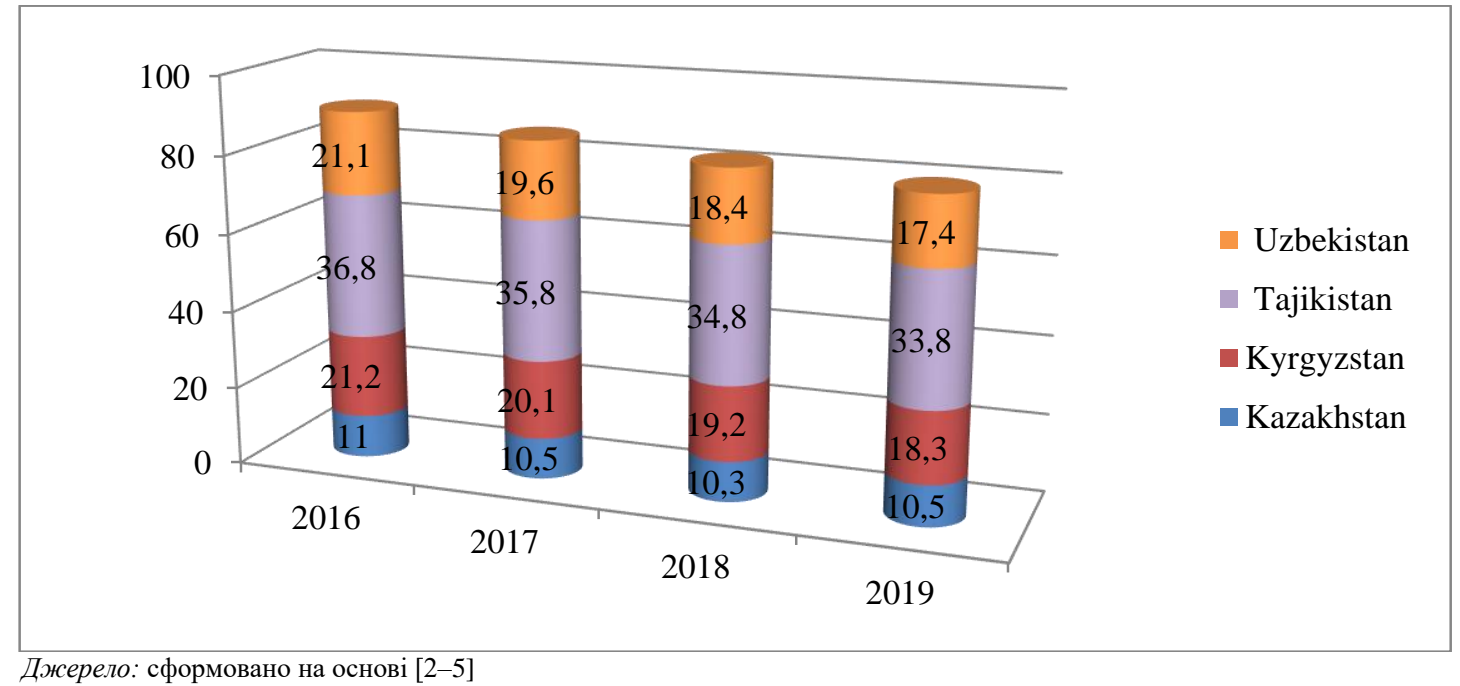

Рис. 5. Оцінка коефіиієнта смертності серед дітей віком до 5 років у краӥнах Центральної Азї, 2016-2019 рр. 


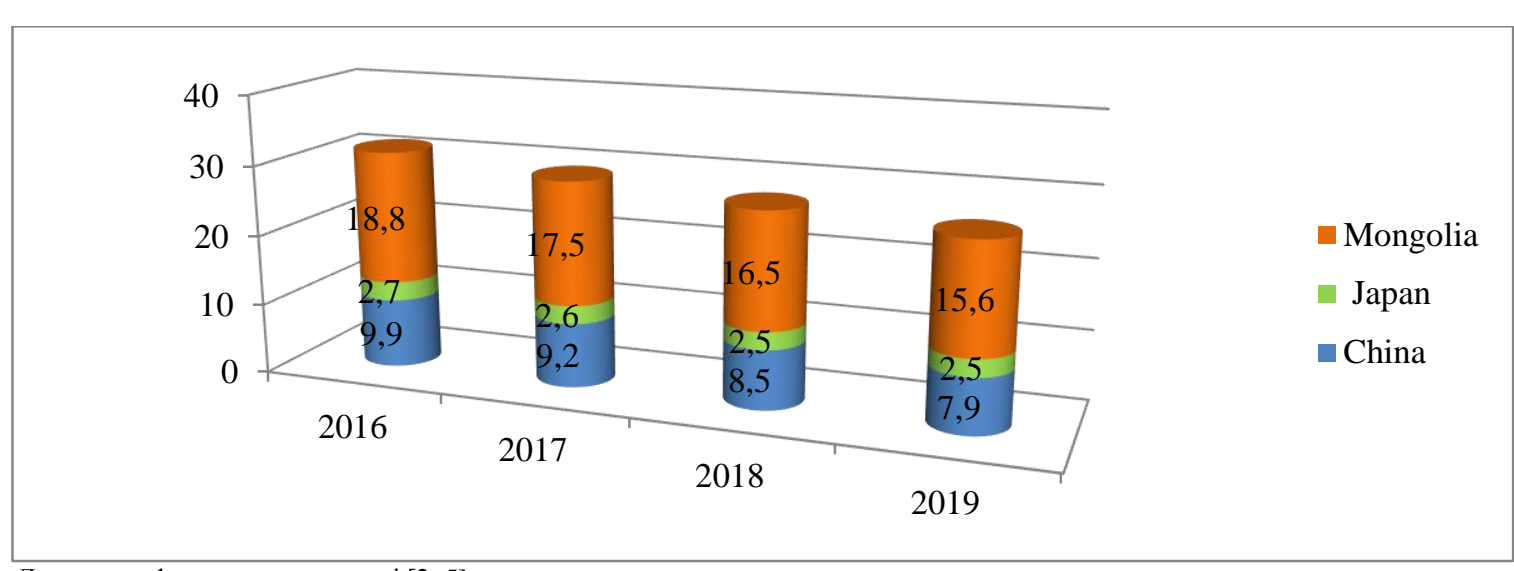

Джерело: сформовано на основі [2-5]

Рис. 6. Оиінка коефіцуієнта смертності серед дітей віком до 5 років у краӥнах Східної Азї, 2016-2019 рр.

Щодо коефіцієнта смертності у країнах Східної Азії (рис. 6), то найвищий показник спостерігається у Монголії, а саме протягом 2016-2019 рр. цей показник коливався в межах 15,6-18,8 смертей на 1000 живонароджених. Наступною країною за чисельністю представлено Китай, а ії показники смертності знижувалися протягом досліджуваного періоду з 9,9 до 7,9 смертей на 1000 живонароджених. Найменшу кількість дитячих випадків смертей зафіксовано у Японії, де смертність складає близько 2,5-2,7 смертей на 1000 живонароджених.

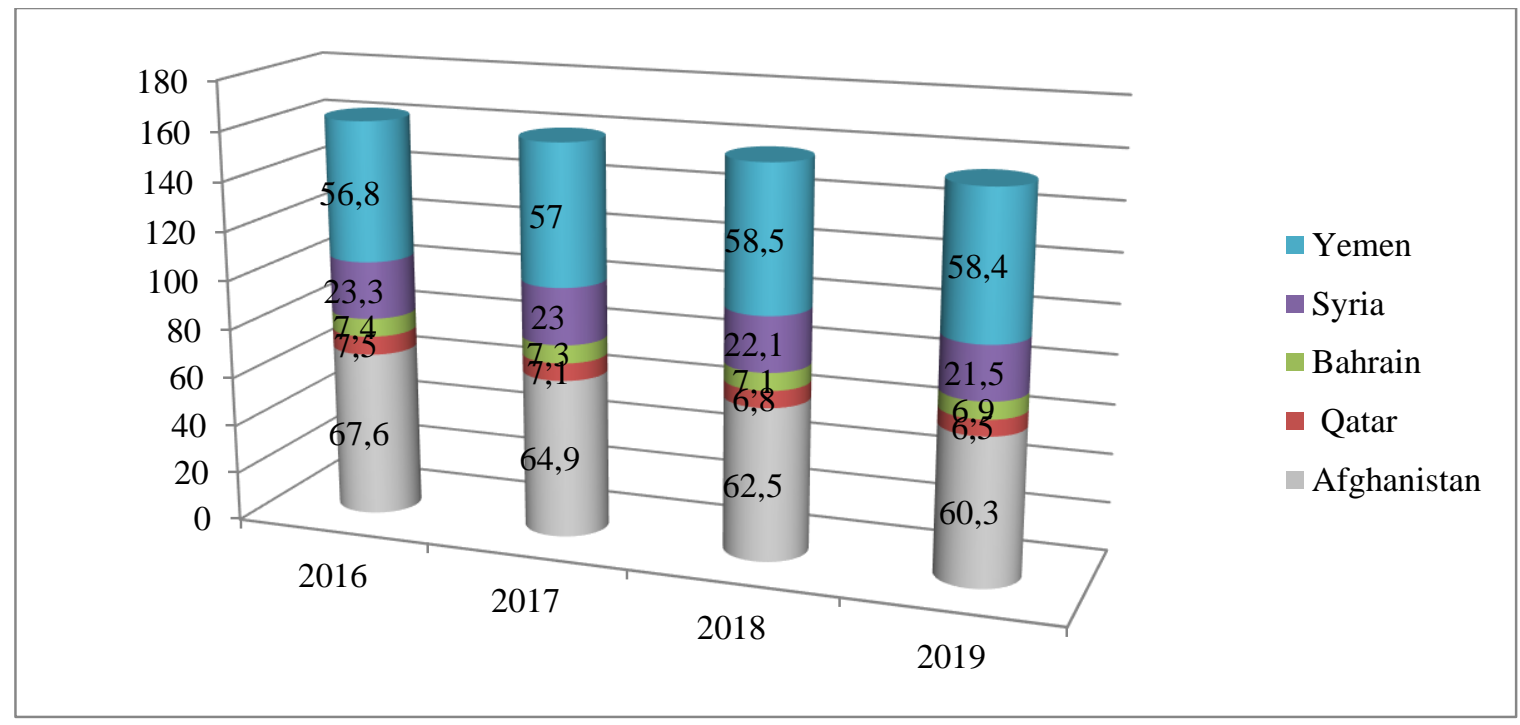

Джерело: сформовано на основі [2-5]

Рис. 7. Оцінка коефіцієнта смертності серед дітей віком до 5 років у країнах Південно-Західної Азії, 2016-2019 рр.

Серед країн Південно-Західної Азії (рис. 7) найбільша кількість смертей зосереджено в Афганістані. Велика кількість смертей дітей віком до 5 років пов'язана 3 ускладненнями під час пологів, пневмонією та сепсисом [3]. Також значна кількість дитячих смертей зафіксована у Смені протягом 2016-2019 рр., їх кількість коливалася в межах 56,8-58,4 смертей на 1000 живонароджених. При цьому у Смені спостерігається тенденція до збільшення чисельності дитячої смертності протягом досліджуваного періоду. Найменшу кількість дитячої смертності зосереджено у Катарі, адже у 2016-2019 рр. показник смертності коливався в межах 6,5-7,5 смертей на 1000 живонароджених.

На рисунку 8 вказано показники смертності серед дітей віком до 5 років у країнах Південної Америки. Найбільша кількість смертей характерна Парагваї та Венесуелі, а саме в Парагваї протягом всього досліджуваного періоду кількість дитячої смертності коливається в межах 19,4-21,5 смертей на 1000 живонароджених, а от у Венесуелі показник смертності дещо більший та знаходиться у межах 26,029,5 смертей на 1000 живонароджених. Така кількість смертей у цих регіонах спричинена економічною 
кризою в країні, недостачею медикаментів та обладнання в лікарнях і пологових відділеннях, недоїданням у дітей, відсутність водопостачання та санітарних норм у відділеннях лікарень [4].

Решті країн притаманний показник смертності близько 15 дитячих смертей на 1000 живонароджених. Найменшу кількість смертей серед дітей віком до 5 років зафіксовано у Чилі, адже показник становив у 2016 р. близько 7,7 смертей ,а вже на кінець 2019 р. спостерігається зменшення до 7 смертей на 1000 живонароджених.

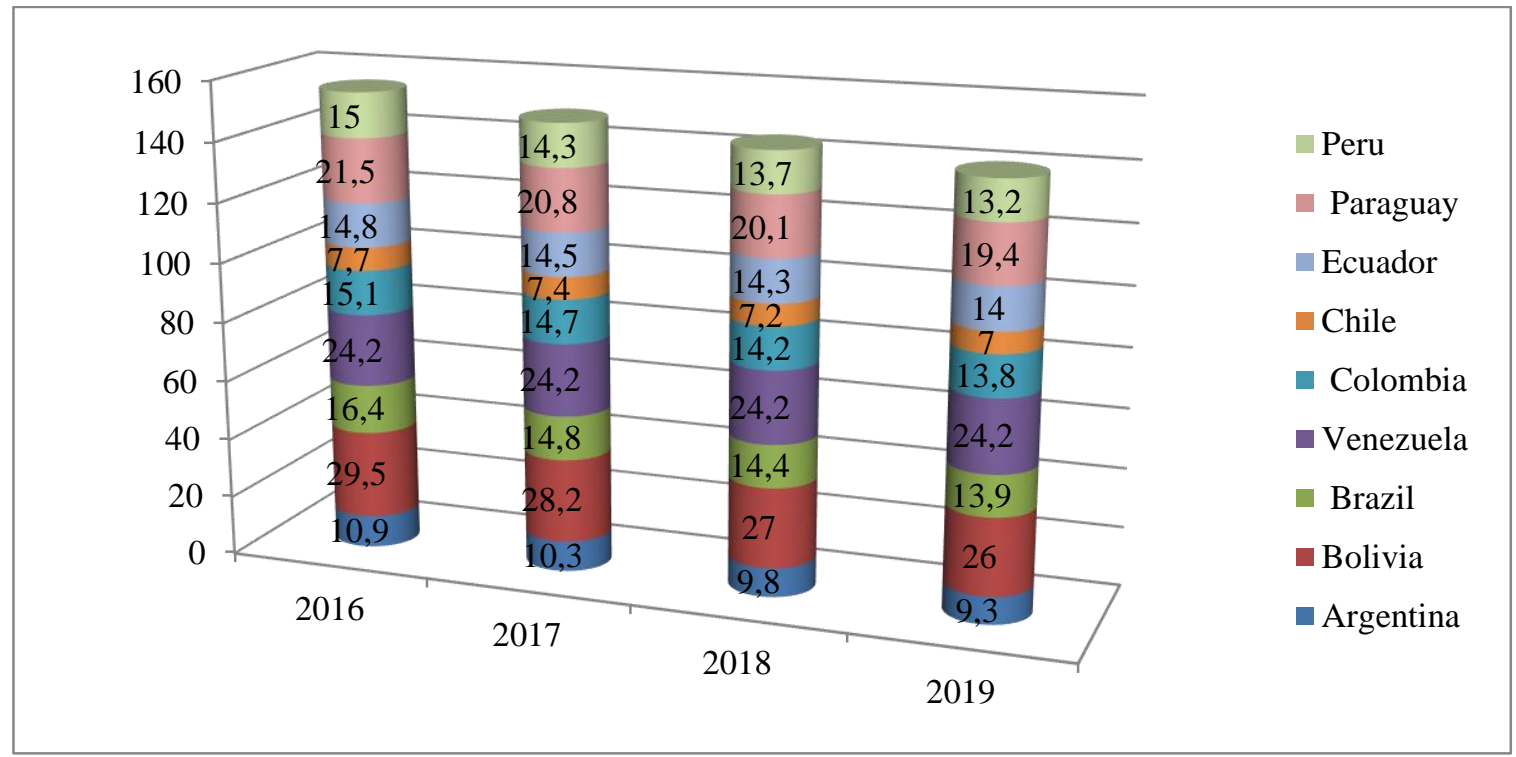

Джерело: сформовано на основі [2-5]

Рис. 8. Оиінка коефіцієнта смертності серед дітей віком до 5 років у краӥнах Південної Америки, 2016-2019 рр.

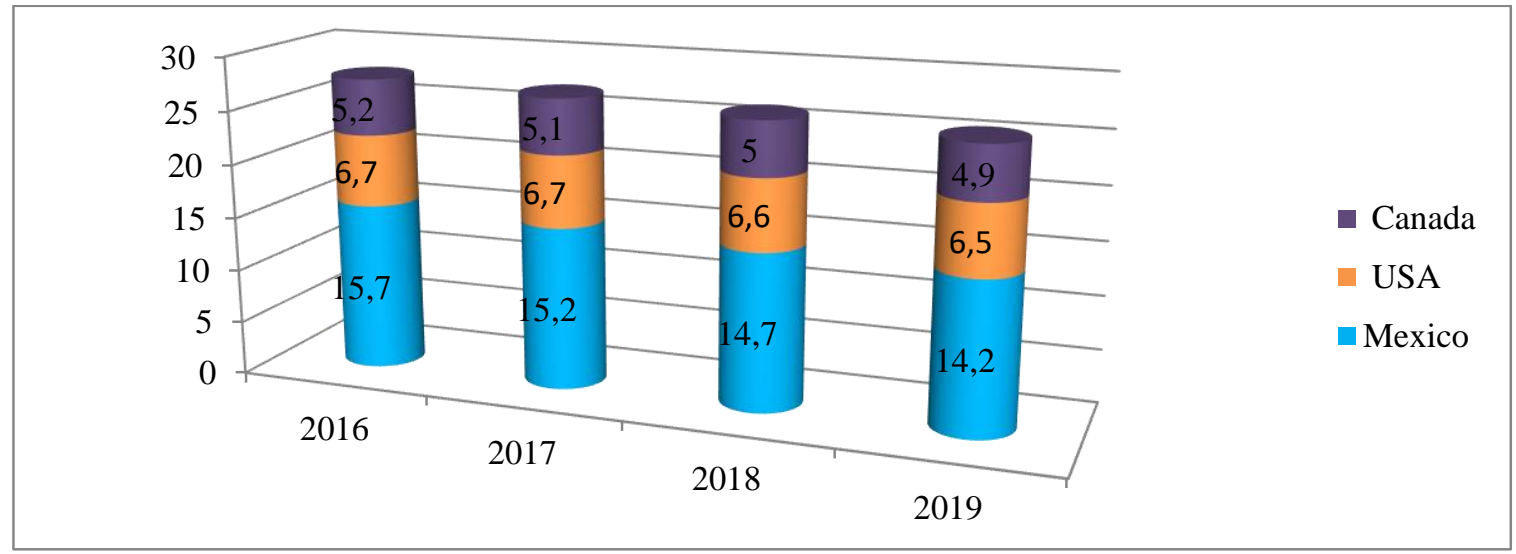

Джерело: сформовано на основі [2-5]

Рис. 9. Оцінка коефіцієнта смертності серед дітей віком до 5 років у краӥнах Північної Америки, 2016-2019 рр.

Значна кількість смертей серед дітей віком до 5 років характерна для Мексики (рис. 9.), адже саме в цій країні зареєстровано найбільшу кількість смертей серед інших досліджуваних країн Північної Америки, протягом всього досліджуваного періоду показник становить 15,7-14,2 смертей на 1000 живонароджених. Варто зауважити, що у Сполучених Штатах Америки кількість смертей протягом 2016-2019 рр. становила понад 6,5-6,7 смертей на 1000 живонароджених. Найменшу кількість смертей зареєстровано у Канаді, їх кількість коливалася протягом зазначеного періоду у межах 4,9-5,2. У всіх зазначених регіонах Північної Америки спостерігається зменшення показника дитячої смертності протягом досліджуваного періоду.

На рисунку 10 вказано значення коефіцієнта дитячої смертності серед країн Австралії та Океанії. Слід зазначити, що найбільшу кількість смертей серед дітей віком до 5 років зафіксовано у Науру. Зокрема, у Науру показник смертності протягом всього періоду коливається в межах 33,9-30,9 смертей 
на 1000 живонароджених та при цьому прослідковується тенденція до збільшення значення показника дитячої смертності. Значення дитячої смертності понад 20 смертей протягом досліджуваного періоду притаманне для Фіджі, Тувалу та Вануату, а саме у Фіджі протягом 2016-2019 рр. показник смертності знаходився у межах 24,7-25,7 смертей, у Тувалу - 26,4-23,9 смертей, у Вануату - 28,0 -25,6 смертей.

Найменшу кількість смертей серед дітей віком до 5 років зафіксовано в Австралії та Новій Зеландії. Показники дитячої смертності протягом досліджуваного періоду у Австралії коливалися в межах близько 3,8-3,6 смертей на 1000 живонароджених. У Новій Зеландії значення дитячої смертності знаходилося в межах 3,3-5,1 смертей на 1000 живонароджених. У цьому регіоні протягом 2016-2019 pp. прослідковується тенденція до зменшення показника дитячої смертності.

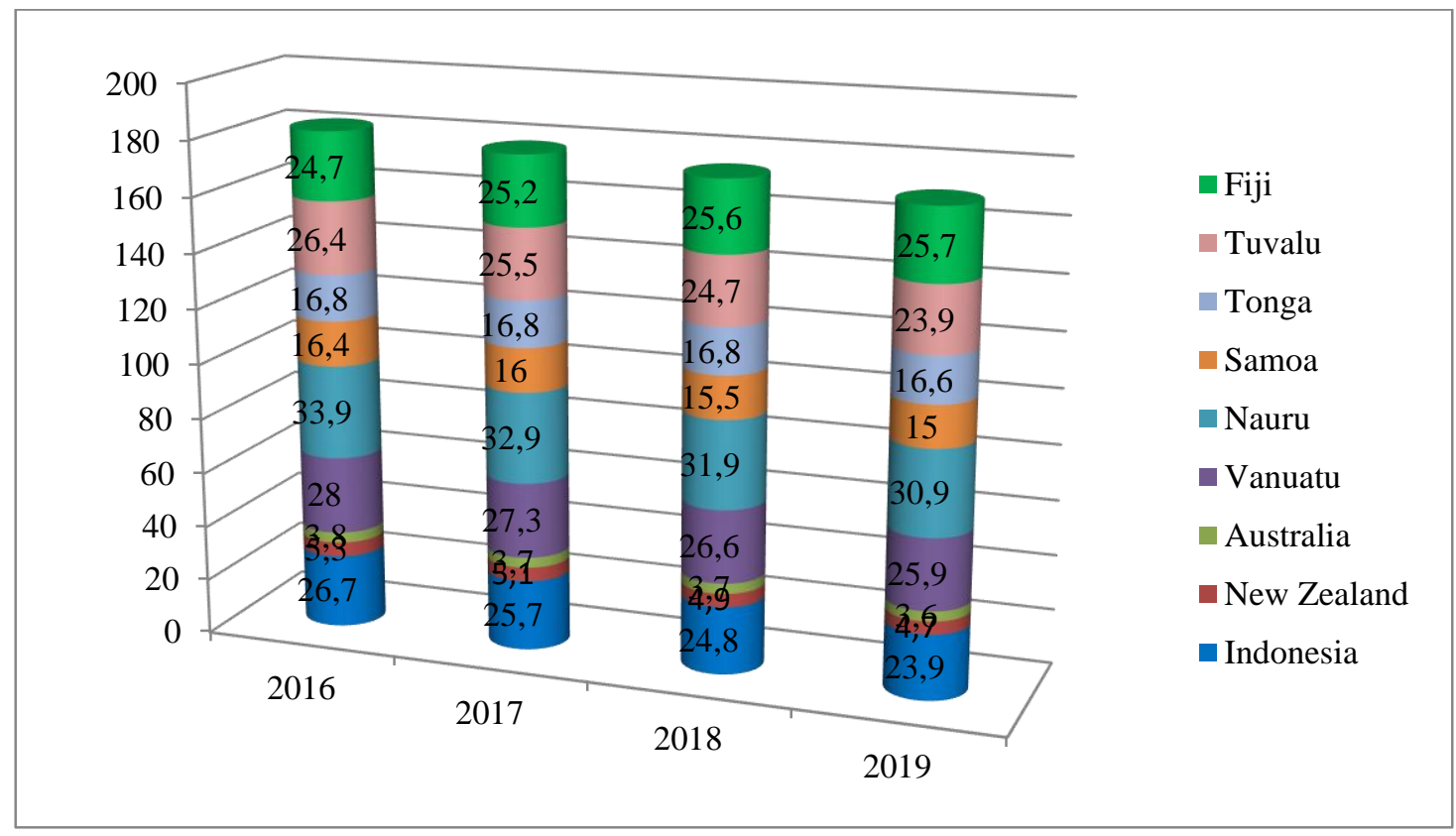

Джерело: сформовано на основі [2-5]

Рис. 10. Оичінка коефіиієнта смертності серед дітей віком до 5 років у країнах Австралії та Океанї̈, 2016-2019 рр.

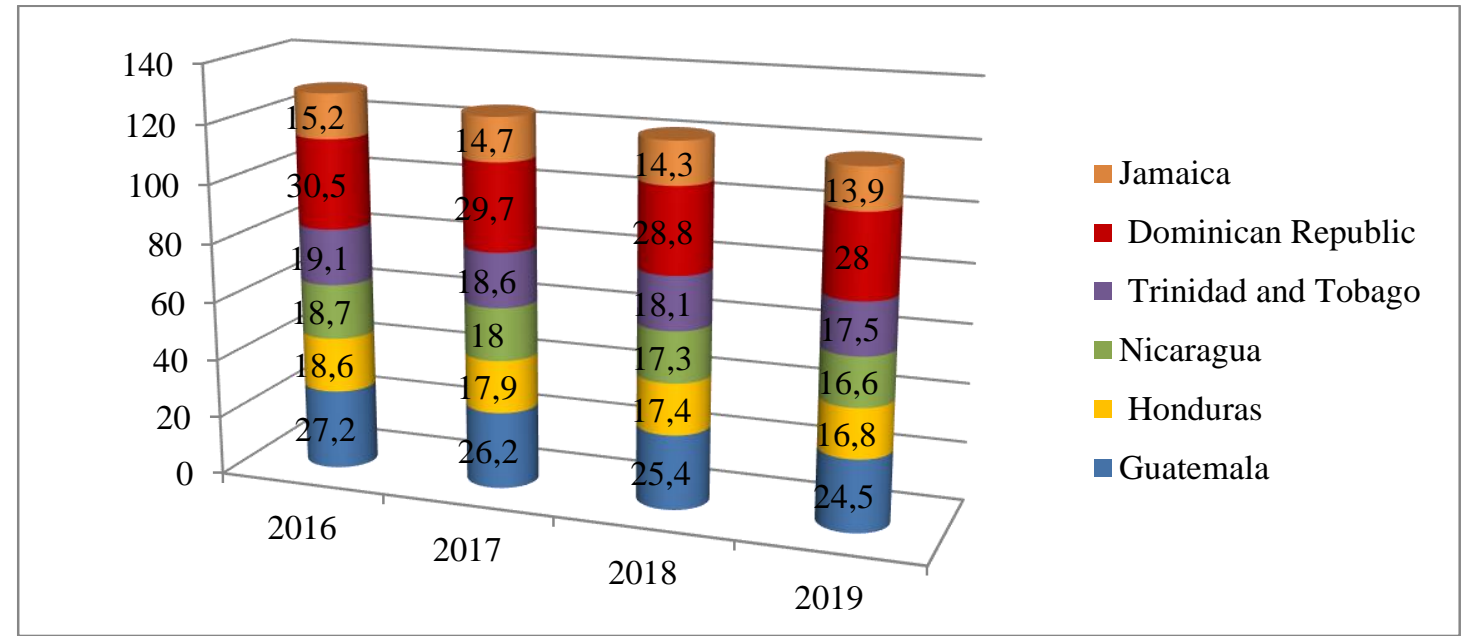

Джерело: сформовано на основі [2-5]

Рис. 11. Оиінка коефіиієнта смертності серед дітей віком до 5 років у країнах Центральної Америки та Кариби, 2016-2019 рр.

На рисунку 11 відображено показники дитячої смертності серед країн Центральної Америки та на Карибах. Варто зазначити, що найбільшу кількість дитячих смертей зафіксовано у Домініканській Республіці, що протягом 2016-2019 рр. становила понад 28 смертей на 1000 живонароджених, тоді як в інших країнах смертність дітей віком до 5 років становила понад 15 смертей, а саме у Гватемалі показник 
смертності коливався в межах 24,5-27,2, у Тринідад та Тобаго значення показника смертності знаходиться у межах 17,5-19,1 та при цьому спостерігається зменшення кількості дитячої смертності. У Нікарагуа та Гондурасі кількість дитячих смертей на кінець досліджуваного періоду перевищувала значення понад 16 смертей на 1000 живонароджених. Найменша кількість дитячих смертей характерна для Ямайки, оскільки близько 15,2 смертей зафіксовано у 2016 р. та на кінець 2019 р. показник знизився до кількості 13,9 смертей на 1000 живонароджених.

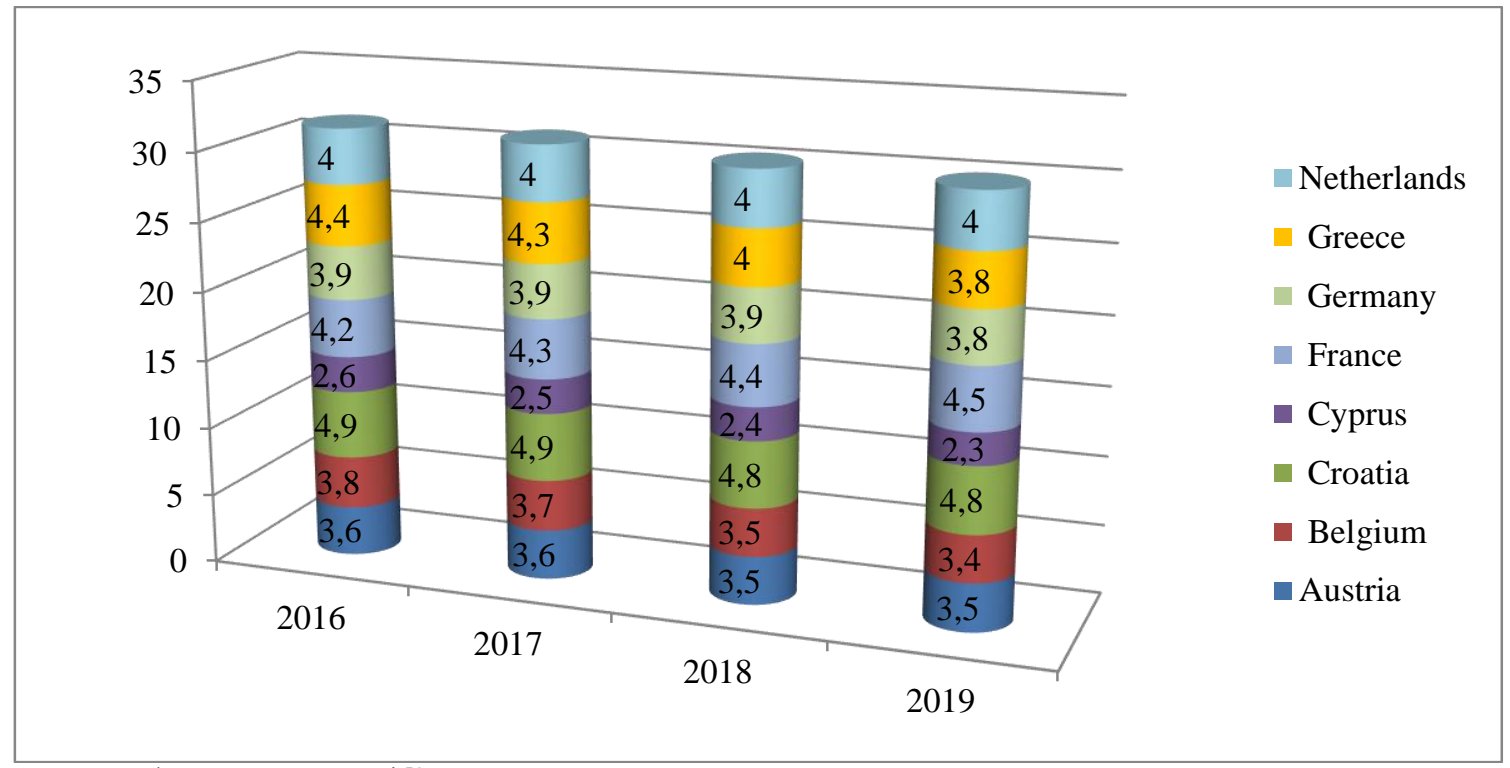

Джерело: сформовано на основі [2-5]

Рис. 12. Оиінка коефійієнта дитячої смертності в Західній Європі, 2016-2019 рр.

Серед країн Західної Європи (рис. 12) найбільша кількість смертей серед дітей віком до 5 років зафіксована у Греції, адже протягом 2016-2019 рр. показник смертності становив близько 3,8-4,4 смертей на 1000 живонароджених. Кількість смертей понад 4 притаманна Нідерландам, Франції та Хорватії. У Німеччині, Бельгії та Австрії кількість смертей серед дітей до 5 років протягом 2016-2019 рр. становить понад 3 смерті на 1000 живонароджених. Найменша кількість смертей - на Кіпрі, оскільки саме у цій країні зафіксовано протягом 2016-2019 рр. понад 2 смерті на 1000 живонароджених.

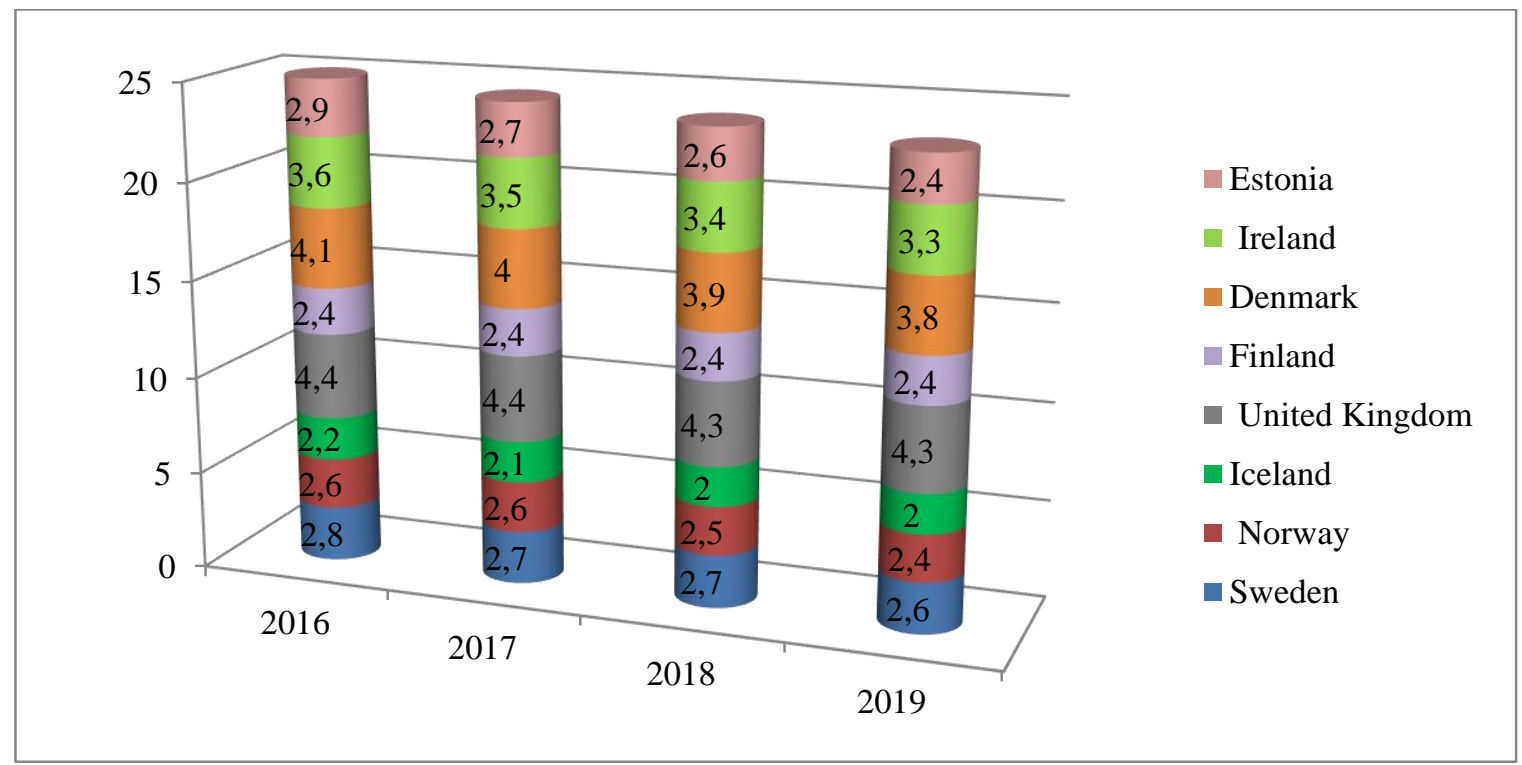

Джерело: сформовано на основі [2-5]

Рис. 13. Оичінка коефіцієєнта дитячої смертності в Північній Європі, 2016-2019 рр. 
На рисунку 13 вказано значення коефіцієнта смертності дітей віком до 5 років у Північній Європі. Слід зазначити, що значна кількість смертей дітей віком до 5 років у Північній Свропі зафіксована у Великобританії, оскільки протягом всього досліджуваного періоду показник смертності коливається в межах 4,3-4,4 смертей на 1000 живонароджених. Серед інших країн зафіксовано понад 2 смерті серед дітей віком до 5 років, а найменшу кількість зареєстровано в Ісландії, адже протягом 2016-2019 рр. значення показника смертності знаходилося у межах 2,0-2,2 смертей.

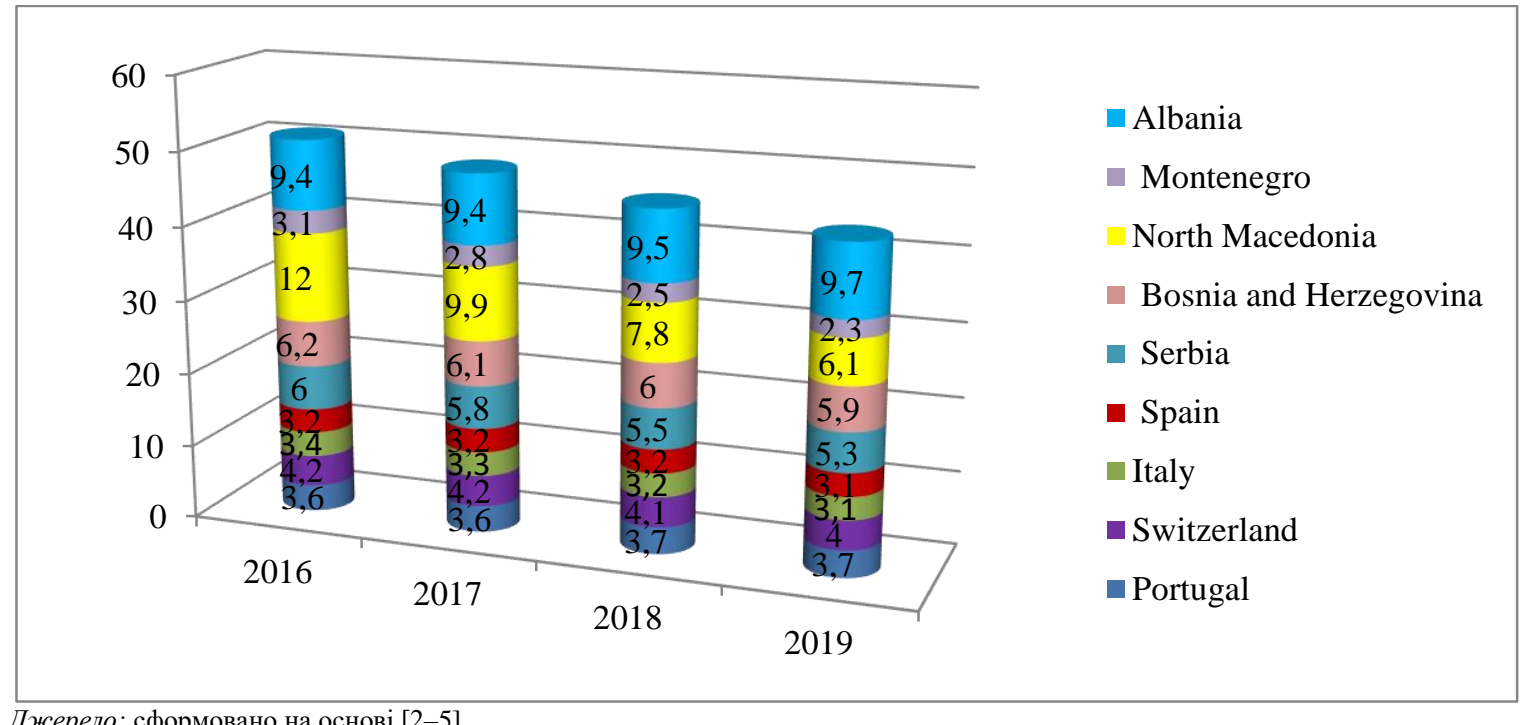

Джерело: сформовано на основі [2-5]

Рис. 14. Оцінка коефійієнта дитячої смертності в Південній Європі, 2016-2019 рр.

На рисунку 14 зображено показники дитячої смертності у Південній Європі, де значна кількість дитячих смертей спостерігається у Албанії та Північній Македонії, їх кількість становить у Македонії 6,1012,0 смертей протягом 2016-2019 рр., а у Албанії показник смертності коливався у межах 9,4-9,7 смертей на 1000 живонароджених. Дещо менша кількість смертей протягом зазначеного періоду зафіксована у Боснії та Герцеговині й Сербії, а саме понад 5 смертей на 1000 живонароджених, близько 4 смертей у Швейцарії. Найменша кількість випадків дитячої смертності - у Чорногорії, Іспанії, Італії та Португалії.

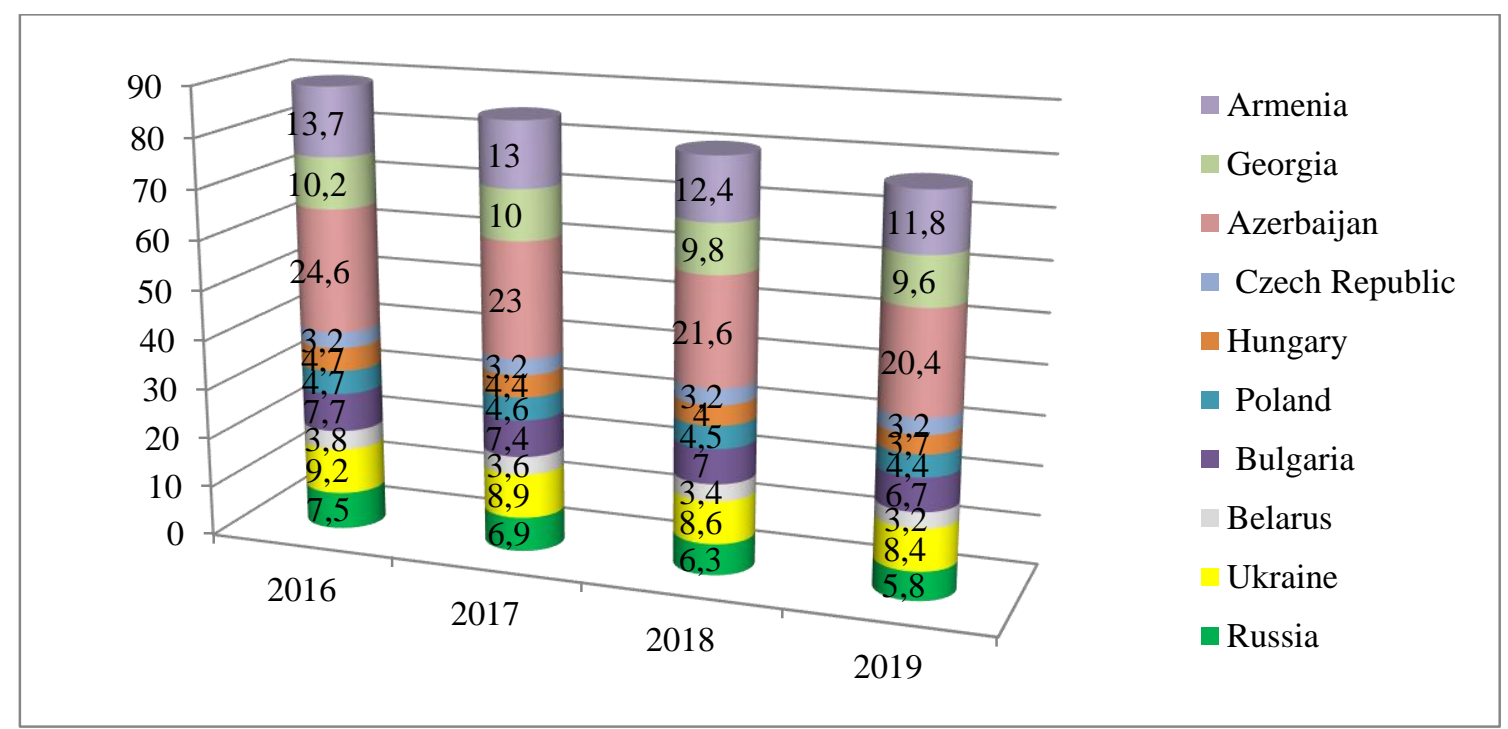

Джерело: сформовано на основі [2-5]

Рис. 15. Оичнка коефіиієнта дитячої смертності в Східній Свропі, 2016-2019 рр.

На рисунку 15 зображено стан показника смертності серед дітей віком до 5 років у Східній Свропі. Щодо стану дитячої смертності у Східній Європі можна констатувати найбільшу кількість летальних випадків серед дітей віком до 5 років у Азербайджані, оскільки кількість смертей перевищила 24,6 у 
2016 р., а у 2019 понад 20,4 смертей на 1000 живонароджених. Основною причиною смертності в Азербайджані $\epsilon$ інфекційні захворювання шлунково-кишкового тракту та проблеми 3 дихальною системою. Наступними країнами за кількістю дитячої смертності понад 9 смертей протягом 20162019 рр. є Вірменія та Грузія. Дещо менші показники смертності (понад 8 смертей) притаманні для України протягом досліджуваного періоду. Найменша кількість смертей серед країн Східної Свропи у 2016-2019 рр. спостерігається у таких регіонах: Чехія та Білорусь. Показники смертності у цих регіонах становлять близько 3 смертей на 1000 живонароджених.

Висновки. Проведене дослідження оцінки коефіцієнта смертності серед дітей віком до 5 років у різних регіонах світу надає можливість зробити висновок, що значна кількість випадків дитячої смертності зосереджена у Мавританії, Судані, Індії, Філіппінах, Камбоджі, Таджикистані, Монголії, Афганістані, Парагваї, Венесуелі, Науру, Домініканській Республіці та Азербайджані. Слід зауважити, що найвищий рівень дитячої смертності зафіксовано у Західній і Центральній Африці. У Центральній Африці припадає понад 100 смертей на 1000 живонароджених дітей. Найменші показники у Західній Європі та Північній Європі близько 4 смертей на 1000 живонароджених. Основними причинами смертей є діарея, малярія, пневмонія, хронічне недоїдання, ускладнення при передчасних пологах, захворювання дихальних шляхів, інфекційні захворювання шлунково-кишкового тракту.

Зниження кількості дитячої смертності в світі можливе завдяки заходам, що спрямовані на реорганізацію медичної системи, вирішення питання оснащення необхідним обладнанням закладів охорони здоров'я, де надається допомога матерям та дітям, створення умов для транспортування дітей, які перебувають у критичному стані, в регіонах Західної Азії необхідним є налагодження водопостачання в медичні заклади, в Африці гострим питанням є недоїдання у дітей, яке потребує негайного вирішення.

\section{Список використаної літератури:}

1. Выживание и здоровье детей // ЮНИСЕФ Таджикистан. - 2017 [Электронный ресурс]. - Режим доступа : https://www.unicef.org/tajikistan/ru/\%D0\%B2\%D1\%8B\%D0\%B6\%D0\%B8\%D0\%B2\%D0\%B0\%D0\%BD\%D0\% B8\%D0\%B5-\%D0\%B8-\%D0\%B7\%D0\%B4\%D0\%BE\%D1\%80\%D0\%BE\%D0\%B2\%D1\%8C\%D0\%B5$\% \mathrm{D} 0 \% \mathrm{~B} 4 \% \mathrm{D} 0 \% \mathrm{~B} 5 \% \mathrm{D} 1 \% 82 \% \mathrm{D} 0 \% \mathrm{~B} 5 \% \mathrm{D} 0 \% \mathrm{~B} 9$.

2. Levels \& Trends in Child Mortality: Report 2017. - New York : UNICEF, 2017 [Electronic resource]. - Access mode : https://childmortality.org/reports.

3. Levels \& Trends in Child Mortality: Report 2018. - New York : UNICEF, 2018 [Electronic resource]. - Access mode : https://childmortality.org/reports.

4. Levels \& Trends in Child Mortality: Report 2019. - New York : UNICEF, 2019 [Electronic resource]. - Access mode : https://childmortality.org/reports.

5. Levels \& Trends in Child Mortality: Report 2020. - New York : UNICEF, 2020 [Electronic resource]. - Access mode : https://childmortality.org/reports.

6. United Nations Inter-Agency Group for Child Mortality Estimation (UN IGME) [Electronic resource]. - Access mode : https://childmortality.org/.

\section{References:}

1. «Vyzhivanie i zdorov'e detei» (2017), YuNISEF Tadzhikistan, [Online], available at: https://www.unicef.org/tajikistan/ru/\%D0\%B2\%D1\%8B\%D0\%B6\%D0\%B8\%D0\%B2\%D0\%B0\%D0\%BD\%D0\% B8\%D0\%B5-\%D0\%B8-\%D0\%B7\%D0\%B4\%D0\%BE\%D1\%80\%D0\%BE\%D0\%B2\%D1\%8C\%D0\%B5$\% \mathrm{D} 0 \% \mathrm{~B} 4 \% \mathrm{D} 0 \% \mathrm{~B} 5 \% \mathrm{D} 1 \% 82 \% \mathrm{D} 0 \% \mathrm{~B} 5 \% \mathrm{D} 0 \% \mathrm{~B} 9$

2. «Levels \& Trends in Child Mortality: Report 2017» (2017), UNICEF, New York, [Online], available at: https://childmortality.org/reports

3. «Levels \& Trends in Child Mortality: Report 2018» (2018), UNICEF, New York, [Online], available at: https://childmortality.org/reports

4. «Levels \& Trends in Child Mortality: Report 2019» (2019), UNICEF, New York, [Online], available at: https://childmortality.org/reports

5. «Levels \& Trends in Child Mortality: Report 2020» (2020), UNICEF, New York, [Online], available at: https://childmortality.org/reports

6. United Nations Inter-Agency Group for Child Mortality Estimation (UN IGME), [Online], available at: https://childmortality.org/

Криничко Фелікс Романович - здобувач кафедри економічної безпеки, публічного управління та адміністрування Державного університету «Житомирська політехніка».

Наукові інтереси:

- державна політика у сфері громадського здоров'я. 